\title{
HUBUNGAN ANTARA PERILAKU PEMULUNG DENGAN KEJADIAN PENYAKIT CACINGAN DI TEMPAT PEMBUANGAN AKHIR SAMPAH SUMOMPO KOTA MANADO
}

\author{
Ronald I. Ottay \\ Bagian Ilmu Kedokteran Pencegahan Fakultas Kedokteran \\ Universitas Sam Ratulangi Manado \\ Email: ronald_rio75@yahoo.co.id
}

\begin{abstract}
Helminthiasis is still one of the social health problems in Indonesia. According to former research, the prevalence of helminthiasis was still high (60-70\%). Garbage collectors at garbage dumps belong to a group, which has a high risk of getting this disease. People's behavior is a major factor to determine their health status, especially in relation to helminthiasis. People's behavior consists of three domains: knowledge, attitude, and action. The aim of this study is to analyze the correlation between the behavior (knowledge, attitude, and action) of garbage collectors and the prevalence of helminthiasis at Sumompo garbage dump Manado City. The research method is a descriptive analysis with a cross sectional study approach. Seventy two respondents were used in a purposive method. The data were collected by using questionaires, and then tabulated and analyzed by using the Chi Square test. The result of this study showed that people's knowledge and attitudes have correlations with helminthiasis, but people's actions have no correlation with helminthiasis among the collectors at the Sumompo garbage dump Manado City. This result indicated that people's behavior was a major factor in determining the prevalence of helminthiasis. While facing the high prevalence of helminthiasis at the Sumompo garbage dump, we have to improve the people's behaviour, especially the domain of action, with the hope that we can increase the health status of the people in that area.
\end{abstract}

Keywords: helminthiasis, behavior, garbage collector

\begin{abstract}
Abstrak: Penyakit cacingan masih merupakan salah satu masalah kesehatan masyarakat di Indonesia. Data penelitian sebelumnya ditemukan prevalensi penyakit cacingan sebesar 6070\%. Para pengumpul sampah (pemulung) di Tempat Pembuangan Akhir Sampah (TPA) merupakan kelompok yang rentan terhadap penularan penyakit ini. Perilaku masyarakat sangat menentukan status kesehatan mereka khususnya kejadian cacingan. Perilaku masyarakat terbagi atas tiga domain yaitu pengetahuan, sikap dan tindakan. Tujuan dari penelitian ini yaitu untuk menganalisis hubungan antara pengetahuan, sikap dan tindakan pemulung terhadap kejadian cacingan di TPA Sumompo Kota Manado. Metode penelitian yang digunakan yaitu deskriptif analitik dengan pendekatan potong lintang (cross sectional study). Jumlah sampel dalam penelitian ini yaitu 72 responden. Data diambil menggunakan kuesioner, ditampilkan dalam tabel lalu dianalisis menggunakan uji khi kuadrat. Hasil penelitian ini menunjukkan bahwa pengetahuan dan sikap pemulung mempunyai hubungan dengan kejadian cacingan, sedangkan tindakan pemulung tidak mempunyai hubungan dengan kejadian cacingan di TPA Sumompo Kota Manado. Hasil ini menunjukkan bahwa perilaku masyarakat sangat menen-tukan terjadinya penyakit cacingan. Dari penelitian ini dapat disimpulkan bahwa perilaku pemulung tentang pengetahuan dan sikap mempunyai hubungan dengan kejadian cacingan dan tindakan pemulung tidak mempunyai hubungan dengan kejadian cacingan di TPA Kota Manado, sehingga diperlukan peningkatan perilaku masyarakat dalam menjaga status kesehatan mereka khususnya terhadap penyakit cacingan.
\end{abstract}

Kata kunci: cacingan, perilaku, pemulung 
Salah satu faktor yang mempengaruhi kesehatan, baik individu maupun kesehatan masyarakat tersebut ialah masalah lingkungan. Hal ini disebabkan oleh karena lingkungan merupakan tempat manusia maupun agen penyakit dapat tumbuh dan berkembang secara bersama-sama. Banyak penyakit infeksi yang terjadi di negara-negara berkembang merupakan hasil dari pencemaran lingkungan. Salah satunya pencemaran lingkungan yang terjadi karena pembuangan tinja tanpa adanya metode pengolahan yang tepat. Hal ini dapat dipicu akibat kondisi sosial ekonomi serta pengetahuan kesehatan lingkungan yang kurang.

Cacing-cacing usus yang menjadi persoalan kesehatan masyarakat di Indonesia mencakup 4 spesies utama yaitu Ascaris lumbricoidei, Trichuris trichiura, Necator americanus, dan Ancylostoma duodenale. Jenis cacing-cacing di atas memiliki distribusi geografik khususnya di daerah pedesaan yang memiliki sanitasi lingkungan yang kurang dan kebiasaan penggunaan tinja sebagai pupuk kebun. Berdasarkan data yang diperoleh dari World Health Organization (WHO/Badan Kesehatan Dunia), di dunia ditemukan lebih dari 2 milyar penduduk terinfeksi cacing. Prevalensi yang tinggi ditemukan terutama di negara-negara nonindustri (sedang berkembang). ${ }^{1,2,3}$ Diperkirakan 800 juta -1 milyar penduduk dunia terinfeksi Ascaris, 700-900 juta terinfeksi cacing tambang dan 500 juta terinfeksi Trichuris sp. Di Indonesia penyakit cacing merupakan masalah kesehatan masyarakat terbanyak setelah malnutrisi. ${ }^{4}$

Penelitian ini dilakukan di TPA Sumompo yang merupakan tempat aktifitas dari petugas pengumpul sampah. Namun, selain petugas pengumpul sampah, terdapat pula aktifitas pemulung yang bekerja tanpa alat pelindung diri yang memadai. Dari hasil wawancara dengan aparat kelurahan, jumlah pemulung sebanyak 250 orang. Oleh karena itu, peneliti tertarik untuk melakukan pemeriksaan tinja untuk mengetahui apakah terdapat kandungan telur cacing (khususnya jenis nematoda usus), pada mereka yang bekerja sebagai pemulung dan hubungannya dengan perilaku mereka.
Penelitian ini bertujuan untuk mengetahui hubungan antara perilaku pemulung dengan kejadian penyakit cacingan.

\section{TINJAUAN PUSTAKA}

Cacing-cacing usus yang merupakan persoalan kesehatan masyarakat di Indonesia mencakup 4 spesies utama yaitu Ascaris lumbricoides, Trichuris trichiura, Necator americanus, dan Ancylostoma duodenale. $^{5}$

Epidemiologi penyakit kecacingan selalu berhubungan erat dengan keterbelakangan dalam pembangunan sosial ekonomi dan erat kaitannya dengan sindroma kemiskinan. Tanda-tanda dari sindroma ini antara lain berupa penghasilan yang sangat rendah. Keadaan ini menyebabkan tidak dapat mencukupi kebutuhan sandang, pangan dan perumahan, kuantitas dan kualitas makanan yang rendah, sanitasi lingkungan yang jelek dan sumber air bersih yang kurang, pelayanan kesehatan yang terbatas, jumlah anggota keluarga yang besar dan tingkat buta aksara yang tinggi. ${ }^{6}$

Perilaku merupakan suatu kegiatan atau aktivitas organisme (makhluk hidup) yang bersangkutan, sehingga yang dimaksud perilaku manusia, yaitu tindakan atau aktivitas dari manusia itu sendiri yang mempunyai bentangan yang sangat luas antara lain: berjalan, berbicara, menangis, tertawa, bekerja, kuliah, menulis, membaca dan sebagainya. Menurut Skiner seorang ahli psikologi, perilaku merupakan respon atau reaksi seseorang terhadap stimulus (rangsangan dari luar). ${ }^{7}$

Perilaku manusia merupakan hasil dari segala macam pengalaman serta interaksi manusia dengan lingkungannya yang terwujud dalam bentuk pengetahuan, sikap dan tindakan. Dengan kata lain, perilaku merupakan respon atau reaksi seorang individu terhadap stimulus yang berasal dari luar maupun dari dalam dirinya. Respon ini dapat bersifat pasif (tanpa tindakan seperti berpikir, berpendapat, dan bersikap) maupun aktif (melakukan tindakan). Sesuai dengan batasan ini, perilaku kesehatan dapat dirumuskan sebagai segala bentuk pengala- 
man dan interaksi individu dengan lingkungannya, khususnya yang menyangkut pengetahuan, dan sikap tentang kesehatan, serta tindakannya yang berhubungan dengan kesehatan. $^{7}$

Blum mengemukakan bahwa ada empat faktor yang berperan dalam meningkatkan status kesehatan, yaitu: hereditas, pelayanan kesehatan, perilaku dan lingkungan. Blum juga menyimpulkan bahwa lingkungan mempunyai peran yang paling besar terhadap status kesehatan, kemudian berturut-turut disusul oleh perilaku mempunyai peran terbesar kedua, pelayanan kesehatan dan keturunan mempunyai peran yang paling kecil terhadap status kesehatan. ${ }^{8}$

\section{METODE PENELITIAN}

Penelitian ini dilaksanakan di TPA Sumompo Manado pada bulan April-Mei 2009. Sampel yang digunakan yaitu tinja para pemulung. Penelitian ini merupakan penelitian analitik. Data yang dikumpulkan yaitu perilaku para pemulung dan kejadian cacingan.

\section{HASIL PENELITIAN}

Hasil dalam penelitian ini menunjukkan bahwa antara pengetahuan dengan kejadian cacingan memperoleh nilai Probabilitas sebesar 0,006 $(<0,05)$ yang berarti ada hubungan antara pengetahuan dengan kejadian cacingan.

Pengetahuan berhubungan dengan banyaknya informasi yang dimiliki seseorang, melalui kenyataan (fakta) dengan melihat dan mendengar sendiri, serta melalui alat-alat komunikasi, misalnya membaca surat kabar, mendengar radio, menonton televisi dan sebagainya. Hal-hal demikian diterima dengan panca indera untuk kemudian diterima dan diolah oleh otak dan juga diperoleh dari pengalaman sendiri. Proses pengolahan informasi yaitu menerima informasi, mengolahnya, menyimpannya dan menghasilkan kembali yang meliputi sensasi, persepsi, memori dan berpikir. Sensasi merupakan proses menangkap sti- muli. Persepsi merupakan proses memberi makna pada sensasi sehingga individu memperoleh pengetahuan baru. Dengan kata lain, persepsi merubah sensasi menjadi informasi. Memori merupakan proses menyimpan informasi dan menggalinya kembali. Berpikir ialah mengolah dan memanipulasikan informasi untuk memenuhi kebutuhan atau memberikan respon.

Hasil penelitian ini sejalan dengan penelitian yang dilakukan oleh Maryanti ${ }^{9}$ yang menganalisis tentang hubungan perilaku pemakaian APD dan kebersihan diri dengan kejadian infeksi cacing tambang pada 64 pengrajin batu bata di Desa Tegal Badeng Timur yang menemukan bahwa adanya hubungan antara pengetahuan dengan kejadian infeksi cacing tambang.

Penelitian lainnya yang berjudul upaya pemberantasan cacingan melalui penyuluhan yang dilakukan secara eksperimen semu menggunakan rancangan ulang non random dengan 241 murid kelas $\mathrm{V}$ di SDN Cimanggu II dan SDN Cimanggu III memperoleh hasil yaitu peningkatan pengetahuan akan menurunkan prevalensi cacingan murid SD. Peningkatan pengetahuan ini dilakukan dengan metode penyuluhan. Hasil penelitian lainnya yang dilakukan tentang pengaruh program pemberantasan kecacingan terhadap perilaku orang tua murid Sekolah Dasar di Kelurahan Pisangan Baru Jakarta Timur menunjukkan bahwa peningkatan tingkat pengetahuan merupakan salah satu indikator keberhasilan program pemberantasan kecacingan. ${ }^{10,11}$

Hasil analisis data antara sikap dengan kejadian cacingan memperoleh nilai Probabilitas sebesar 0,001 yang berarti adanya hubungan antara sikap dengan kejadian cacingan pada para pemulung sampah di Tempat Pembuangan Akhir Sampah Sumompo Manado.

Adanya hubungan antara kedua variabel ini yaitu sikap dan kejadian cacingan disebabkan karena secara umum sikap merupakan kecenderungan untuk merespon atau bertindak (secara positif atau negatif) terhadap orang, objek atau situasi tertentu. Sikap merupakan organisasi yang relatif menetap dari perasaan-perasaan, keyakin- 
an-keyakinan dan kecenderungan perilaku terhadap orang lain, kelompok, ide-ide, atau objek-objek tertentu.

Sikap dapat dikatakan juga sebagai suatu hal yang yang menentukan sifat, hakikat, baik perbuatan sekarang maupun yang akan datang. Jadi sikap timbul karena ada stimulus. Sikap seseorang tidak selamanya tetap, sikap dapat berkembang ketika mendapat pengaruh baik dari dalam maupun dari luar yang bersifat positif dan mengesankan. Sikap tidak terbentuk tanpa interaksi manusia terhadap objek tertentu atau suatu objek. Hal-hal di atas yang menyebabkan sikap berhubungan atau berpengaruh terhadap keadaan kesehatan atau fisik seseorang termasuk bisa tidaknya terkena suatu penyakit seperti cacingan.

Hasil penelitian ini sejalan dengan penelitian yang dilakukan oleh Maryanti (2006) yang menganalisis tentang hubungan perilaku pemakaian APD dan kebersihan diri dengan kejadian infeksi cacing tambang pada 64 pengrajin batu bata di Desa Tegal Badeng Timur yang menemukan bahwa adanya hubungan antara sikap dengan kejadian infeksi cacing tambang. ${ }^{\text {' }}$

Hasil penelitian yang dilakukan oleh Prasetya (2009) tentang pengaruh program pemberantasan kecacingan terhadap perila$\mathrm{ku}$ orang tua murid Sekolah Dasar di Kelurahan Pisangan Baru Jakarta Timur menunjukkan bahwa peningkatan sikap merupakan salah satu indikator keberhasilan program pemberantasan kecacingan. Penelitian lainnya tentang upaya pemberantasan cacingan melalui penyuluhan yang dilakukan secara eksperimen semu menggunakan rancangan ulang non random dengan 241 murid kelas V di SDN Cimanggu II dan SDN Cimanggu III memperoleh hasil yaitu peningkatan sikap akan menurunkan prevalensi cacingan murid SD. Peningkatan pengetahuan ini dilakukan dengan metode penyuluhan. ${ }^{10,11}$

Hasil penelitian ini menunjukkan bahwa sikap seseorang terhadap suatu objek merupakan perasaan mendukung atau memihak (favourable) maupun perasaan tidak mendukung atau memihak (unfavourable) pada objek tersebut. Sikap merupakan suatu pola perilaku atau tendensi atau kesiapan antisipatif, predisposisi untuk menyesuaikan diri dalam situasi sosial. ${ }^{12}$

Secara sederhana, sikap dapat dikatakan merupakan respon terhadap stimuli sosial yang telah terkondisikan atau semakin kurang sikap seseorang atau masyarakat terhadap pemberantasan cacingan maka akan semakin besar kemungkinan timbulnya cacingan.

Hasil analisis data memperoleh hasil yaitu antara tindakan dengan kejadian cacingan memperoleh nilai Probabilitas sebesar 0,149 yang lebih besar dari 0,05, sehingga $\mathrm{H}_{0}$ diterima yaitu tidak ada hubungan antara tindakan dengan kejadian cacingan pada pemulung di Tempat Pembuangan Akhir Sampah Sumompo Manado.

Seperti telah disebutkan di atas bahwa sikap adalah kecenderungan untuk bertindak. Sikap belum tentu terwujud dalam tindakan, sebab untuk terwujudnya tindakan perlu faktor pendukung atau suatu kondisi yang memungkinkan antara lain yaitu adanya fasilitas.

Ketiadaan hubungan antara tindakan dengan kejadian cacingan dapat disebabkan beberapa hal seperti jumlah sampel penelitian. Jumlah sampel penelitian sangat menentukan hasil yang diperoleh. Hubungan antara kedua variabel ini bisa saja terjadi jika jumlah sampel diperbanyak (lebih dari 100 responden). Hal ini bisa dilihat pada penelitian-penelitian lain yang memperoleh hasil bahwa adanya hubungan yang signifikan antara tindakan dengan kejadian cacingan karena menggunakan jumlah sampel yang lebih besar dari penelitian ini.

Selain jumlah responden penelitian, hal-hal yang bisa menyebabkan perbedaan hasil penelitian ini yaitu keadaan lingkungan pada saat dilakukan penelitian misalnya musim, ketersediaan air bersih dan sebagainya. Seperti yang dikatakan oleh Bloom bahwa faktor lingkungan sangat mempengaruhi status kesehatan seseorang. Jadi, perbedaan keadaan lingkungan juga akan mempengaruhi hasil penelitian.

Hal lainnya yaitu karakteristik responden yang berbeda dengan penelitian lainnya. Karakteristik responden seperti umur, pen- 
didikan dan keadaan sosial ekonomi responden. Jadi, hasil ini bisa diperoleh hanya pada lokasi penelitian ini dengan waktu dan situasi lingkungan yang khusus.

Penelitian tentang cacingan dilakukan terhadap 241 murid sekolah dasar di Cimanggu II dan III, Kedung Jaya II dan Cibuluh II tentang perbedaan antara upaya penanggulangan cacingan dengan dan tanpa penyuluhan yang memperoleh hasil bahwa dengan kegiatan penyuluhan program pemberantasan cacingan terjadinya peningkatan pengetahuan, sikap dan perilaku cacingan sehingga dapat menurunkan prevalensi cacingan pada murid SD. ${ }^{11}$ Agoes (2008) melaksanakan penelitian tentang perilaku cuci tangan sebelum makan dan kecacingan pada murid SD di Kabupaten Pesisir Selatan Sumatera Barat menunjukkan bahwa adanya hubungan antara perilaku cuci tangan menggunakan air dan sabun sebelum makan, buang air besar tidak di jamban dan jajan bukan di warung sekolah dengan kejadian cacingan yang dilakukan pada 257 murid SD. ${ }^{13}$

Selain itu, menurut Priyono (2007) ditemukan adanya pengaruh perilaku defekasi dan cuci tangan terhadap kejadian Ascariasis pada siswa SDN 03 Lampeji Kecamatan Mumbulsari Kabupaten Jember dimana 35 siswa menderita infeksi cacing usus (32 siswa menderita ascariasis dan 3 siswa enterobiasis) dan 51 siswa tidak menderita infeksi cacing usus. ${ }^{14}$

Penelitian lainnya yang dilakukan oleh Maryanti (2006) terhadap 64 orang pengrajin batu bata di Desa Tegal Badeng Timur memperoleh hasil bahwa adanya hubungan antara penggunaan alat pelindung diri, penggunaan alas kaki, kebiasaan buang air besar dengan kejadian infeksi cacing tambang, sedangkan kebiasaan mencuci tangan dan memelihara kuku tidak berhubungan secara signifikan dengan kejadian infeksi cacing tambang. Prasetya (2009) yang melakukan penelitian tentang pengaruh program pemberantasan kecacingan terhadap perilaku orang tua murid Sekolah Dasar di Kelurangan Pisangan Baru Jakarta Timur menunjukkan bahwa dengan adanya program pemberantasan kecacingan maka pengetahuan responden bertambah sehingga prevalensi cacingan akan semakin rendah. ${ }^{9,10}$

Penelitian yang dilakukan oleh Purba, dkk (2003) tentang faktor-faktor yang berhubungan dengan kejadian Sistiserkosis pada Penduduk Kecamatan Wamena Kabupaten Jayawijaya Propinsi Papua Tahun 2002 memperoleh hasil yaitu adanya hubungan antar kejadian cacingan (sistiserkosis) dengan kebiasaan cuci tangan, jenis pekerjaan, frekuensi mandi, jenis sumber air bersih dan tempat buang air besar. ${ }^{15}$

\section{KESIMPULAN}

Berdasarkan hasil analisis data menunjukkan bahwa perilaku berhubungan dengan kejadian cacingan pada masyarakat di Tempat Pembuangan Akhir Sampah Sumompo Kota Manado.

\section{DAFTAR PUSTAKA}

1. Adams EJ, Stephenson LS, Latham MC. Physical activity and growth of Kenyan school children with hookworm in trichuris trichiura and ascaris lumbricoides infections are improved after treatment with albendazol. Journal of American Institute of Nutrition. 1994; 2(1): 1200-1205.

2. Bundy DAP, De Silva H. Sosioeconomic and behavioral factor affecting the prevalence of geohelminths in preschool children. Journal Southeast Asian J Trop Med Public Health. 1998; Vol. 1(27): 3642.

3. De Silva. Helminthic infections of urban and rural school children in Penang island Malaysia: Implications for Control. Southeast Asian Journal Tropical Medical Public Health. 1996; 28(1): 596-598.

4. Departemen Kesehatan Republik Indonesia 2001. Profil Kesehatan Indonesia. Jakarta, 2000.

5. Ginting S. Cacing dan perumahan. [homepage on the Internet]. 2002. [diakses pada 23 Maret 2009]. Available from: http:// www. journal.unair.ac.id

6. Depary AA. Pemeriksaan tinja untuk diagnosis helminthiasis. Majalah Kedokteran Indonesia. 1991; 3(1): 206-211. 
7. Notoatmodjo S. Pendidikan dan perilaku kesehatan. Jakarta: Rineka Cipta, 2003; Hal. 114-127.

8. Bustan MN. Pengantar epidemiologi. Jakarta: Rineka Cipta, 2002; p. 26-27.

9. Maryanti. Hubungan perilaku pemakaian APD dan kebersihan diri dengan kejadian infeksi cacing tambang: Studi di desa Tegal Badeng Timur kecamatan Negara kabupaten Jembrana propinsi Bali. [homepage on the Internet]. 2006 [diakses pada 17 Juni 2009]. Available from: http://www.adln.lib.unair.ac.id/go. php?id=gdlhub-gdl-s1-2006-maryanti2695\&PHPSES SID=be6b5aaa328275c $585572270 f 6 f a 22 \mathrm{c} 7$

10.Prasetya L. Pengaruh program pemberantasan kecacingan terhadap perilaku orang tua murid sekolah dasar di kelurahan Pisangan Baru Jakarta Timur. [homepage on the Internet]. 2009 [Diakses pada 17 Juni 2009]. Available from: http://www.digilib.ui.ac.id/opac/themes/li bri2/detail.jsp?id=81768\&lokasi=lokal

11.Perbedaan antara upaya penanggulangan cacingan dengan dan tanpa penyuluhan. [homepage on the Internet] 2009. [diakses pada 17 Juni 2009] http://www.
digilib.ui.ac.id/helper/viewKoleksi.jsp?id $=80948 \&$ lokasi $=$ lokal $\&$ template $=$ Abstrak Inggris.detail.template

12.Azwar S. Sikap Manusia: Teori dan pengukurannya. Edisi Kedua. Yogyakarta: Pustaka Pelajar, 2003.

13.Agoes D. Perilaku cuci tangan sebelum makan dan kecacingan pada murid SD di kabupaten Pesisir Sumatera Barat. Jurnal Kesehatan Masyarakat Nasional. 2008; 2(6): 30-39.

14.Priyono S. Pengaruh perilaku defekasi dan cuci tangan terhadap kejadian ascariasis pada siswa-siswi SDN 03 Lampeji kecamatan Mumbulsari kabupaten Jember. [homepage on the Internet]. 2007. [Diakses pada 17 Juni 2009] http://digilib.unej.ac.id/go.php?id=gdlhub -gdlgrey-2008-sigidpriyo2028\&PHPSE $\mathrm{SSID}=5 \mathrm{c} 1 \mathrm{e} 63 \mathrm{a} 5 \mathrm{be} 3 \mathrm{a} 16 \mathrm{~b} 018 \mathrm{cf} 137 \mathrm{f} 36691$ $\mathrm{b} 8 \mathrm{c}$

15.Purba WH, Miko TY, Ito A. Faktor-faktor yang berhubungan dengan kejadian sistiserkosis pada penduduk kecamatan Wamena kabupaten Jayawijaya propinsi Papua tahun 2002. Jurnal Makara Kesehatan. $2003 ; 7(2): 21-30$. 